\title{
REPRESENTASI ISLAMI DALAM ANIMASI "NuSSa" SEBAGAI MEDIA PEMBELAJARAN UNTUK ANAK
}

\author{
Fathin Hanifah Langga \\ Mahasiswa Magister Desain, Fakultas Seni Rupa dan Desain \\ Institut Teknologi Bandung \\ Jalan Ganesha No. 10 Bandung, 40132 \\ No.Hp.: +62 812-1445-0689,E-mail: fathinlangga@gmail.com \\ Hafiz Aziz Ahmad \\ DosenFakultas Seni Rupa dan Desain \\ Institut Teknologi Bandung \\ Jalan Ganesha No. 10 Bandung, 40132 \\ E-mail: hafiz@dkv.itb.ac.id \\ Alvanov Zpalanzani Mansoor \\ DosenFakultas Seni Rupa dan Desain \\ Institut Teknologi Bandung \\ Jalan Ganesha No. 10 Bandung, 40132 \\ E-mail: Nova.zp@gmail.com
}

\begin{abstract}
ABSTRAK
Pendidikan Islami merupakan tuntunan dalam kehidupan umat muslim. Media film/ video/animasi di YouTube dianggap sebuah media yang efektif dalam menyampaikan pendidikan Islam. Animasi "Nussa" merupakan serial animasi dengan konten edutainment islami untuk orang tua dan anak-anak. Penelitian ini bertujuan untuk membahas representasi visual keislaman dalam animasi "Nussa". Metode penelitian yang digunakan adalah analisis isi berbasis analisis visual Gillian Rose. Representasi islami dalam animasi"Nussa" ini tidak hanya dapat dilihat dari segi cerita atau visual , tetapi juga dapat dilihat dari berbagai kombinasi seluruh konsep elemen atau atribut yang terkait didalamnya. Hal ini dapat dilihat dari pemilihan warna, adegan, penampilan tokoh (kostum), dialog, dan pemilihan nama tokoh. Dari analisis yang ada ditemukan bahwa berbagai penggunaan elemen dan atribut yang didominasi nuansa keislaman saling mendukung satu sama lain sehingga memperkuat citra animasi "Nussa' sebagai edutainment dengan representasi islami.
\end{abstract}

Kata kunci: representasi islami, animasi, analisis visual, web series

\section{ABSTRACT}

Islamic Representation in "Nussa" Animation as Learning Media for Children. Islamic education is a guide in the lives of Muslims. Films / videos / animations media on YouTube is considered as effective media in conveying Islamic education. "Nussa" animation is an animated series with Islamic edutainment content for parents and children. This study aims to discuss the Islamic visual representation in "Nussa" animation. The research method used was discourse analysis based on Gillian Rose"s visual analysis. The Islamic representation in "Nussa" animation cannot only be seen in term of the story or visual, but also can be seen from various combinations of all concepts of elements or related attributes in it. This can be seen from selection of colours, scenes, appearance of characters (costumes), dialogue, and character's name 
selection. The finding from the analysis showed that various uses of elements and attributes which are dominated by islamic nuance support each other in bringing out the image of " "Nussa"' animation as an edutainment with an Islamic representation.

Keywords: islamic representation animation, visual analysis, web series

\section{PENDAHULUAN}

Penggunaan internet menjadi alternatif yang memudahkan masyarakat untuk memilih tontonan. Adanya internet memungkinkan tambahan-tambahan siaran yang lebih interaktif (Haqqu, 2020). Hal tersebut dapat ditemui dalam salah satu media sosial berbasis video bernama YouTube (Dylewski, Mikula, Tryjanowski, Morelli, \& Yosef, 2017; MacLeod et al., 2015).

Bagi umat muslim, pendidikan Islami merupakan tuntunan dalam kehidupan. Melalui survei yang dilakukan Langga, orang tua beranggapan bahwa media yang paling efektif untuk menyampaikan pendidikan islami kepada anak adalah media film/video/animasi, sebagian besar orang tua merekomendasikan film/video/animasi yang terdapat di internet/ YouTube (Albantani \& Madkur, 2017; Langga et al., 2019; Xu, Park, Kim, \& Park, 2016).

Animasi "Nussa" merupakan salah satu dari beberapa animasi yang populer di YouTube. Belakangan ini "Nussa" telah menarik perhatian masyarakat Indonesia sehingga animasi "Nussa" seringkali viral diberbagai media sosial. Animasi "Nussa" merupakan tayangan bertema islami yang dapat ditonton secara gratis pada YouTube Channel "Nussa" Official yang diunggah setiap minggunya pada hari Jumat. Akun resmi YouTube milik "Nussa" Official ini hanya dengan waktu 5 bulan sejak rilis perdananya telah mencapai lebih dari 3,3 juta subscribersyang setia menunggu episodeepisode terbaru setiap minggunya.

Film yang berkualitas idealnya memiliki fungsi edukasi dan memberikan penerangan kepada masyarakat. Ukuran yang dapat digunakan dalam mencapai standardisasi estetikanya adalah konten dan pesan yang berkualitas dari segi informasi dan edukasi (Dylewski et al., 2017; Kaynak, Kaya, \& Aykaç, 2020; Larouche et al., 2016; Rohman, 2016).

Animasi "Nussa" merupakan serial animasi dengan konten edutainment yang menyenangkan untuk anak-anak dan orang tua dalam menjelajahi petualangan mini dan memecahkan masalah kehidupan sehari-hari "Nussa" dan adik perempuannya Rarra dengan fondasi kehangatan Islam (Brohi, Brohi, \& Bhatti,2018; Mitra, 2019; Ramji,2016).Animasi terdiri dari berbagai elemen pembentuk film yang dapat membentuk persepsi dalam pikiran seseorang akan informasi dan nilai estetis yang hendak disampaikan. Elemen naratif, elemen visual, dan elemen suara dirancang sedemikian rupa agar dapat mengomunikasikan sebuah informasi. Elemen visual menjadi bagian penting dalam membuat subjek tampil menarik dengan susunan atau komposisi gambar dan warna yang enak dipandang sehingga informasi dapat tersampaikan kepada penonton. Tujuan penelitian ini adalah membahas representasi islami dalam animasi "Nussa" sebagai media pembelajaran untuk anak.

Media pembelajaran berarti suatu medium, perantara, atau pengantar yang digunakan dengan tujuan untuk pembelajaran atau pendidikan. Media harus disesuaikan dengan kompetensi yang ingin dicapai atau tujuan pembelajarannya (Elbih, 2015; Qayyum \& Mahmood, 2015; Saleem \& Ramasubramanian, 2019). Hal tersebut 
merupakan kriteria yang paling utama dalam pemilihan media pembelajaran (Umar, 2014). Kepasrahan (keimanan) kepada Allah berdasarkan pada petunjuk ajaran Islam (Alquran dan Hadis) dan pembentukan tingkah laku islami (akhlak mulia) merupakan tujuan akhir pendidikan Islam (Jannah, 2002). Sementara itu, dalam UU No. 20 Tahun 2003 dijelaskan bahwa tujuan pendidikan nasional adalah untuk berkembangnya potensi peserta didik agar menjadi manusia yang beriman dan bertakwa kepada Tuhan Yang Maha Esa, berakhlak mulia, sehat, berilmu, cakap, kreatif, mandiri, dan menjadi warga negara yang demokratis serta bertanggung jawab.

\section{METODE PENELITIAN}

Metodepenelitianyangdigunakanadalah analisis isi berbasis analisis visual dari Gillian Rose. Secara umum, penelitian ini menganalisis teks visual yang merepresentasikan pendidikan Islami dalam animasi "Nussa". Objek yang akan diteliti adalah animasi "Nussa" secara keseluruhan dan bukan per episode.

\section{PEMBAHASAN}

Penyampaian konten islami dari segi visual yang paling dominan dapat dilihat melalui penampilan setiap tokoh. Semua tokoh yang dihadirkan dalam animasi "Nussa" tampil dalam nuansa islami yang kental. Pakaian dan aksesoris Nussa, Rarra, dan Umma adalah pakaian dan aksesoris yang digunakan oleh umat muslim.
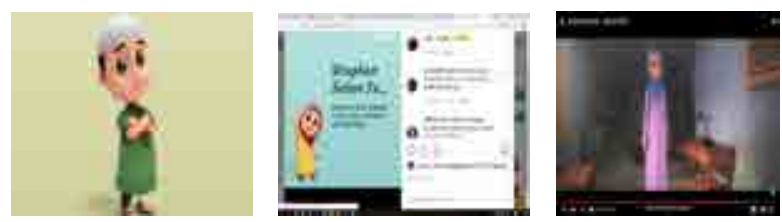

Gambar 1 Tokoh Nussa, Rarra, dan Umma (https://www.facebook.com/kartun"Nussa"rara/, 2019)
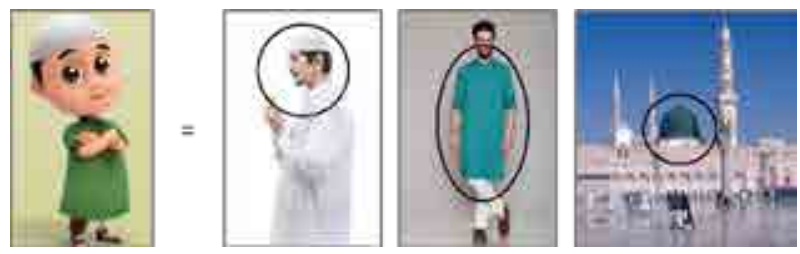

Gambar 2 Representasi Penampilan Tokoh Nussa

Nussa menggunakan busana muslim baju kurtal warna hijau dan celana panjang warna cokelat. Baju kurtal adalah baju dengan panjang selutut atau diatasnya tanpa kerah. Baju kurtal umumnya dipakai untuk aktivitas ibadah. Aksesoris peci yang digunakan Nussa berwarna putih atau sering disebut peci haji. Sandal yang digunakan Nussa adalah jenis sandal gunung berwarna hitam yang biasa digunakan oleh laki-laki. Kaki kiri Nussa menggunakan kaki palsu tepat di lutut. Rarra menggunakan busana muslim gamis warna kuning. Gamis merupakan baju panjang sampai bawah lutut, berlengan panjang, dan longgar. Kerudung dan sepatu yang dipakai Rarra berwarna merah. Kerudung hanya menutupi bagian kepala dan panjangnya tidak sepanjang khimar. Umma mengenakan busana muslim gamis warna merah muda dan khimar warna biru. Berbeda dengan kerudung yang dikaitkan di leher, khimar menutupi kepala hingga ke bagian depan dan belakang dada sehingga lekuk dada tidak terlihat. 
Tabel 1 Manajemen Warna pada Animasi "Nussa" (Nugroho, 2015)

\begin{tabular}{|c|c|c|c|}
\hline Warna & Asosiasi & Karakter & $\begin{array}{c}\text { Simbol atau } \\
\text { Lambang }\end{array}$ \\
\hline Hijau & $\begin{array}{l}\text { Sesuatu } \\
\text { yang hidup } \\
\text { dan berkem- } \\
\text { bang }\end{array}$ & $\begin{array}{l}\text { Segar, } \\
\text { muda, hidup }\end{array}$ & $\begin{array}{l}\text { Kesetiaan, } \\
\text { kesegaran, } \\
\text { kemudaan, } \\
\text { keremajaan, } \\
\text { keyakinan, } \\
\text { kepercayaan, } \\
\text { keimanan }\end{array}$ \\
\hline Putih & $\begin{array}{l}\text { Salju, } \\
\text { sinar putih } \\
\text { berkilau }\end{array}$ & $\begin{array}{l}\text { Positif, } \\
\text { cerah, tegas }\end{array}$ & $\begin{array}{l}\text { Sinar kesucian, } \\
\text { kemurnian, } \\
\text { kejujuran, } \\
\text { ketulusan, } \\
\text { kedamaian, } \\
\text { ketentraman, } \\
\text { kesopanan, } \\
\text { kelembutan. }\end{array}$ \\
\hline Cokelat & $\begin{array}{l}\text { Warna tanah } \\
\text { atau warna } \\
\text { natural }\end{array}$ & $\begin{array}{l}\text { Kedekatan } \\
\text { hati, } \\
\text { sopan, arif, } \\
\text { bijaksana, } \\
\text { hemat, } \\
\text { hormat }\end{array}$ & $\begin{array}{l}\text { Kesopanan, } \\
\text { kearifan, } \\
\text { kebijaksanaan, } \\
\text { kehormatan }\end{array}$ \\
\hline Kuning & $\begin{array}{l}\text { Pada sinar } \\
\text { matahari, } \\
\text { bahkan pada } \\
\text { mataharinya } \\
\text { sendiri }\end{array}$ & $\begin{array}{l}\text { Terang, } \\
\text { gembira, } \\
\text { ramah, } \\
\text { supel, riang, } \\
\text { cerah }\end{array}$ & $\begin{array}{l}\text { Kecerahan, } \\
\text { kegembiraan, } \\
\text { kemeriahan, } \\
\text { kecermelangan }\end{array}$ \\
\hline Merah & $\begin{array}{l}\text { Pada darah } \\
\text { dan juga api }\end{array}$ & $\begin{array}{l}\text { Kuat, } \\
\text { energik, } \\
\text { berani, } \\
\text { positif }\end{array}$ & Berani \\
\hline $\begin{array}{l}\text { Merah } \\
\text { muda }\end{array}$ & Merah muda & $\begin{array}{l}\text { Wanita atau } \\
\text { feminin }\end{array}$ & $\begin{array}{l}\text { Cinta, } \\
\text { romantisme, } \\
\text { eksentrik }\end{array}$ \\
\hline Biru & Biru & $\begin{array}{l}\text { Air, laut, } \\
\text { langit, es }\end{array}$ & $\begin{array}{l}\text { Melankolis, } \\
\text { sayu, sendu, } \\
\text { tenang }\end{array}$ \\
\hline
\end{tabular}

Penggunaan warna putih pada peci Nussa dan warna hijau pada baju Nussa sebagai tokoh utama melambangkan warna keislaman. Warna putih dan hijau merupakan beberapa warna yang disebutkan dalam Alquran. Pakaian terbaik adalah yang berwarna putih. Dalam beberapa ayat Alquran, warna hijau diletakkan di satu tempat yang mulia dan dipandang indah oleh Allah SWT. Warna hijau merupakan simbol tumbuh-tumbuhan dan kesejukan. Anas bin Malik mengatakan, "Warna yang paling disukai oleh Rasulullah SAW adalah warna hijau." Warna hijau mampu memberikan kenyamanan pada pandangan mata. Kubah Masjid Nabawi berwarna hijau.Rasulullah SAW selalu menggunakan warna untuk sorban beliau. Barang siapa pada pagi hari memandang tumbuh-tumbuhan yang hijau, matanya akan bersinar dan sehat. Artinya, nuansa hijau merupakan warna kegemaran Nabi SAW dan memiliki makna dalam Islam (Syafi'i, 2017). Selain pada pakaian Nussa, warna hijau juga digunakan pada logo animasi "Nussa".

Jika dilihat dari pemilihan nama Nussa, Rarra, dan Umma, hal ini juga mencerminkan kekhasan dalam penulisan nama-nama islami. Penulisan huruf konsonan dalam abjad Arab yang memiliki tanda syaddah atau tasydid ("), dilambangkan dengan perulangan huruf (konsonan ganda). Sama halnya dengan penulisan latin pada nama tokoh Nussa, Rarra, dan Umma. Jika ditulis latin, penulisan seperti "ss", "rr", "mm" maka dibaca tebal.

Penggunaan warna hijau pada logo dan baju Nussa ditujukan sebagai warna islami. Namun, warna hijau memiliki banyak filosofi, tidak hanya dapat merepresentasikan keislaman, bisa juga merepresentasikan kesuburan atau kesegaran. Warna yang merepresentasikan keislaman pun tidak hanya warna hijau, tetapi warna putih pun dapat melambangkan keislaman. Begitu juga dengan penampilan tokoh pada animasi Nussa, orang yang menggunakan kurtal atau gamis tidak selalu dapat dikatakan sebagai umat muslim. Di negara Arab, kurtal atau gamis tidak hanya digunakan oleh umat muslim.

Adegan-adegan keagamaan dalam animasi "Nussa" tidak ditampilkan secara dominan. Umumnya adegan berdoa dengan mengangkat kedua tangan ke atas merupakan cara berdoa yang dilakukan oleh umat muslim. 


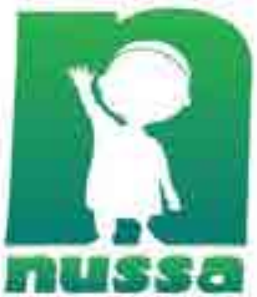

Gambar 3Logo Animasi "Nussa" (https://www.facebook.com/kartun”Nussa"rara/, 2019)
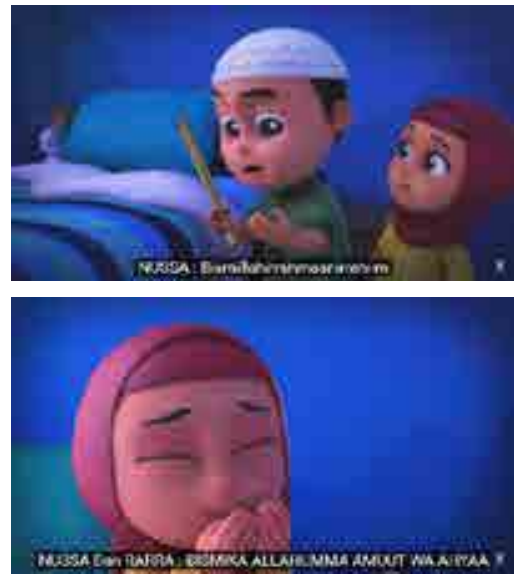

Gambar 4Adegan Berdoa dalam Episode "Nussa": Tidur Sendiri, Gak Takut!
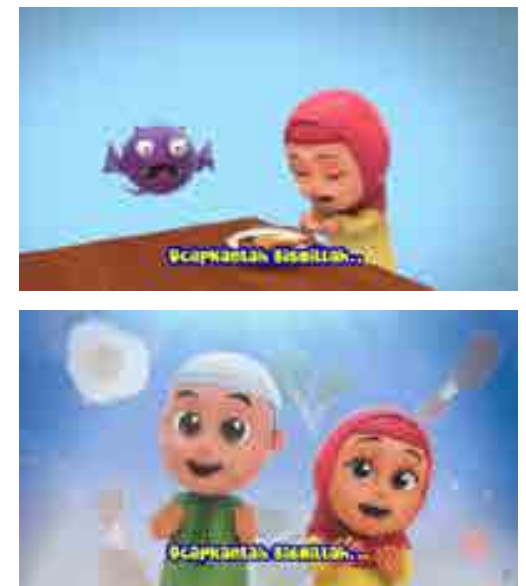

Gambar 5 Adegan Berdoa dalam Episode "Nussa": Makan Jangan Asal Makan

Adegan ini menjadi salah satu bentuk representasi keislaman dalam animasi "Nussa". Mengangkat tangan saat berdoa merupakan hal yang disyariatkan dalam Islam serta salah satu adab dalam berdoabagi umat muslim. Adab ini merupakan salah satu yang membedakan cara berdoa umat muslim dan nonmuslim. Salah satu contoh terdapat perbedaan cara berdoa umat muslim dan umat Kristen. Menangkupkan kedua telapak tangan menjadi satu/melipat tangan adalah cara berdoa umat Kristen untuk menunjukkan ketaatan kepada kehendak Tuhan.

Dialog dalam animasi "Nussa" sangat mendominasi penyampaian pesan nilai-nilai keislaman. Dialog sangat mendukung setiap adegan-adegan yang ditampilkan. Penyampaian nilai-nilai islami dalam animasi "Nussa" tidak banyak digunakan melalui adegan karena adegan disini umumnya memperlihatkan dialog antartokoh dan aktivitas tokoh seharihari dirumah. Adegan seperti ibadah, beriman, dan berakhlak sangat jarang diperlihatkan, umumnya pesan tersebut melalui ucapan-ucapan tokoh. Dialog disesuaikan dengan visualisasi tokoh, seperti karakter dan ekspresinya.

Pada saat Nussa menemani Rarra, Nussa mengajarkan Rarra untuk mempraktikkan adab sebelum tidur yang diikuti pula oleh Rarra. Pertama, Nussa mencontohkan untuk membaca basmalah kemudian menepuknepuk kasur Rarra hingga akhirnya setan kabur ketakutan. Kemudian Rarra menutup jendela, ia bersyukur dengan mengucapkan Alhamdulillah karena kelelahan bermain hingga lupa menutup jendela. Kedua, wudhu dengan tertib dan jangan boros menggunakan air, ketiga membaca ayat kursi dilanjut dengan membaca surah Qul (AlIkhlas, Al-Falaq, dan An-Nas) masing-masing tiga kali kemudian ditiupkan ke tangan, dibasuh ke wajah dan badan, keempat tidur menghadap ke kanan atau ke arah kiblat, terakhir membaca doa sebelum tidur. 
Tabel 2 Dialog dalam Episode

"Nussa": Tidur Sendiri, Gak Takut!

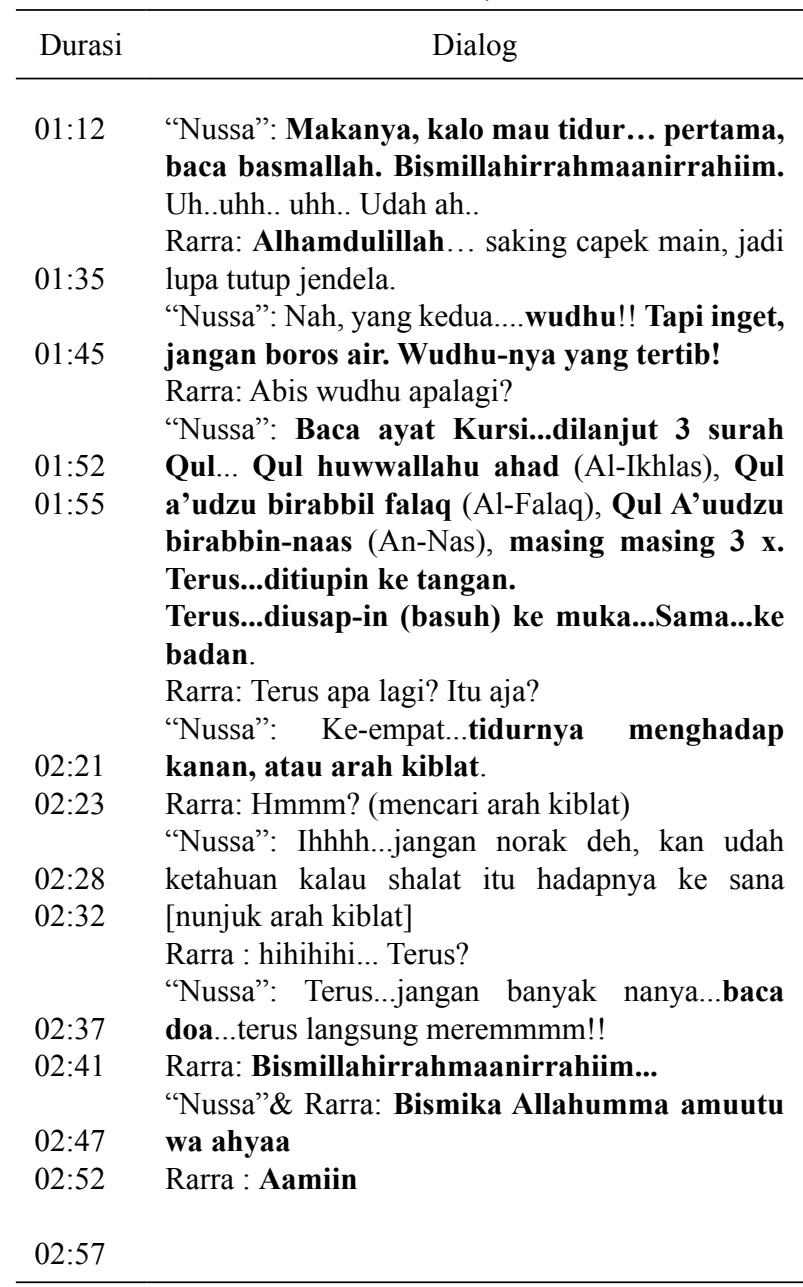

Adab sebelum tidur yang diajarkan oleh Nussa kepada Rarra ini mencerminkan ketakwaan kepada Allah, melaksanakan perintah Allah sesuai tuntunan hadis, yakni sunah Rasul. Sementara itu, doa-doa yang dipanjatkan kepada Allah agar mendapatkan perlindungan dari gangguan setan merupakan bentuk dari beriman kepada Allah.

Nilai-nilai islami dalam animasi Nussa ditampilkan melalui sebuah kisah yang erat hubungannya dengan masyarakat Indonesia. Isi pesan dalam animasi "Nussa" merupakan nasihat yang mengajarkan kebaikan sesuai dengan tuntunan ajaran agama Islam. Animasi "Nussa" hadir sebagai sarana berdakwah tanpa ceramah, menghadirkan masalah yang sering ditemukan dalam kehidupan sehari-hari dan menjawabnya dengan cerita yang ringan. Setiap video menyampaikan pesan dengan sebuah tema utama, tetapi dalam setiap video tersebut tetap menghadirkan pesan-pesan islami yang bisa diterapkan dalam kehidupan sehari-hari.

Hubungan antartokoh dalam animasi "Nussa" dapat merefleksikan hubungan keluarga seperti pada umumnya, hubungan orang tua dan anak serta hubungan antara kakak dan adik. Hubungan orang tua dan anak dalam animasi "Nussa" digambarkan melalui tokoh Umma sebagai orang tua, tokoh Nussa dan Rarra sebagai anak. Tokoh Umma digambarkan sebagai seorang ibu rumah tangga yang sehariharinya mengurus rumah dan anak. Peran Umma selalu mendidik, menjadi penasihat dan contoh teladan bagi Nussa dan Rarra, Umma seringkali mengingatkan Nussa dan Rarra jika mereka berbuat keliru. Cara Umma menasihati Nussa dan Rarra pun menggunakan cara yang islami berdasarkan hadis.Selain itu, juga tidak memarahi dan menggurui, tetapi dengan cara yang baik dan mudah dipahami anak. Anak harus dibiasakan dan dididik dengan bahasa santun (Mudlofir, 2013).

Ungkapanbahasayangsantunmerupakan gambaran manusia yang berkepribadian terpuji. Tokoh Umma digambarkan dengan sosok ibu yang lemah lembut dalam bertutur kata. Ucapan lemah lembut tersebut mengadung harapan agar orang yang diajak bicara menjadi teringat kewajibannya dan takut meninggalkan kewajibannya. Dampaknya, membawa isi pembicaraan yang menggerakkan hati dan mudah memengaruhi orang yang diajak bicara. Ucapan tersebut akan berpengaruh, bukan hanya pada sampainya informasi, tetapi juga pada perubahan pandangan, sikap, dan perilaku orang yang diajak bicara.Hal itu pada akhirnya dapat terlihat dalam tokoh Nussa dan Rarra 
ketika menjadi teringat kewajibannya atau takut meninggalkan kewajibannya. Mereka selalu menuruti nasihat Umma dan memahami setiap penjelasan yang Umma berikan.

Dialog dalam animasi "Nussa" sangat didominasi penyampaian pesan nilai-nilai keislaman. Dan sangat mendukung setiap adegan-adegan yang ditampilkan. Penyampaian nilai-nilai islami dalam animasi "Nussa" tidak banyak digunakan melalui adegan karena adegan disini umumnya memperlihatkan dialog antartokoh dan aktivitas tokoh seharihari dirumah. Adegan seperti ibadah, beriman, dan berakhlak sangat jarang diperlihatkan, umumnya pesan tersebut melalui ucapan-ucapan tokoh. Dialog disesuaikan dengan visualisasi tokoh, seperti karakter dan ekspresinya.

Melalui cara berpakaian para tokoh dan adab yang digambarkan melalui adegan-adegan dalam animasi "Nussa", membuatnya dapat menyampaikan pesan islami dengan cara tidak menggurui, tetapi dengan cara membangun keterikatan dengan penonton melalui contoh teladan dan adegan kegiatan sehari-hari yang pasti dialami dalam kehidupan penonton yang tentu sudah familiar dengan simbolsimbol keislaman secara umum. Mengingat durasinya yang pendek membuat adeganadegan keagamaan tidak ditampilkan secara detail, tetapi didominasi dengan dialog. Oleh karena itu, unsur keislaman secara visual ditampilkan melalui gabungan elemen visual lainnya seperti penampilan tokoh, pemilihan warna, dan pemilihan nama-nama tokoh yang melambangkan keislaman (Gholami \& Rahbar, 2018; Sayfo, 2018).

Animasi "Nussa" menyajikan konten islami melalui cerita dan permasalahan yang ada dalam kehidupan anak sehari-hari. Nilainilai keislamannya dihadirkan dengan materi yang ringan, tidak hanya menyampaikan sebuah teori,tetapi juga memberikan contoh penerapannya secara langsung. Hal ini membuat animasi "Nussa" tidak terkesan menceramahi atau menggurui, seperti contoh pembiasaan melakukan ibadah sehari-hari, pembiasaan mengucapkan kalimat, doa, dan asmaAllah, dan berperilaku terpuji.

Tujuan pendidikan menurut Bloom dalam Turmuzi(2013)dibagi menjadi tiga hal, yakni kognitif, afektif, dan psikomotorik. Maka, contoh pembiasaan sebagaimana yang telah dijelaskan merupakan contoh dari afektif. Pembiasaan (habituation) merupakan proses pendidikan. Pembentukan moral, karakter, internalisasi nilai, atau penanaman afeksi tidak hanya cukup diajarkan melalui kognisi. Menurut Krathwohl, kognisi hanya memberikan kontribusi yang kecil dalam pembentukan afeksi. Aspek afeksi dalam penanamannya memerlukan praktik langsung, perlu adanya pembiasaan tentang nilai-nilai tertentu yang akan ditanamkan. Untuk menanamkan nilainilai islami kepada penonton, khususnya kepada anak-anak, pembiasaan memegang peranan penting. Nilai-nilai (values) hanya bisa dipraktikkan, tidak bisa hanya diajarkan(Rohman, 2016).

\section{SIMPULAN}

Representasi islami dalam animasi "Nussa" ini tidak hanya dapat dilihat dari segi cerita atau visual, tetapi juga dapat dilihat dari berbagai kombinasi seluruh konsep elemen atau atribut yang terkait didalamnya. Untuk membentuk representasi keislaman dalam sebuah animasi dapat dilakukanmelaluiberbagai kombinasi elemen-elemen didalamnya. Dalam animasi "Nussa", representasi keislaman dapat dilihat dari pemilihan warna, adegan, 
penampilan tokoh (kostum), dialog, dan pemilihan nama tokoh. Masing-masing elemen tersebut tidak akan dapat merepresentasikan islami jika hanya berdiri sendiri. Bisa dikatakan bahwa representasi islami juga dapat melalui berbagai penggunaan atribut dan yang didominasi oleh lambang keislaman.

\section{KEPUSTAKAAN}

Albantani, A. M., \& Madkur, A. (2017). “ Musyahadat Al Fidyu": YouTube-Based Teaching and Learning of Arabic as Foreign Language (AFL). Dinamika Ilmu, 17(2), 291-308.

Brohi, A., Brohi, A. S., \& Bhatti, Z. (2018). Using Animation with Multimedia Learning principles for teaching Namaz. International Journal of Computer Science and Emerging Technologies, 2(1), 7-13.

Dylewski, Ł., Mikula, P., Tryjanowski, P., Morelli, F., \& Yosef, R. (2017). Social media and scientific research are complementary-YouTube and shrikes as a case study. The Science of Nature, 104(5-6), 48.

Elbih, R. (2015). Teaching about Islam and Muslims while countering cultural misrepresentations. The Social Studies, 106(3), 112-116.

Gholami, N., \& Rahbar, D. M. (2018). Censorship Strategies In The Subtitled Version Of Animated Movies From English Into Persian. International Journal of Advanced Multidisciplinary Scientific Research (IJAMSR) ISSN: 2581-4281 Vol, $1,2$.

Haqqu, R. (2020). Era Baru Televisi dalam Pandangan Konvergensi Media. REKAM: Jurnal Fotografi, Televisi, Animasi, 16(1), 15-20.

Jannah, F. (2002). Visi Pendidikan Islam Dalam Sistem Pendidikan Nasional. Alqalam, 19(95), 5. https://doi.org/10.32678/ alqalam.v19i95.460
Kaynak, Y., Kaya, C., \& Aykaç, A. (2020). YouTube as a source of premature ejaculation. Revista Internacional de Andrología, 18(2), 63-67.

Langga, F. H., Ahmad, H. A., \& Mansoor, A. Z. (2019). WEB SERIES ANIMASI NUSSA SEBAGAI MEDIA PENDIDIKAN ISLAMI PADA ANAK. Wimba: Jurnal Komunikasi Visual, 10(1).

Larouche, M., Geoffrion, R., Lazare, D., Clancy, A., Lee, T., Koenig, N. A., ... Stothers, L. (2016). Mid-urethral slings on YouTube: quality information on the internet? International Urogynecology Journal, 27(6), 903-908.

MacLeod, M. G., Hoppe, D. J., Simunovic, N., Bhandari, M., Philippon, M. J., \& Ayeni, O. R. (2015). YouTube as an information source for femoroacetabular impingement: a systematic review of video content. Arthroscopy: The Journal of Arthroscopic \& Related Surgery, 31(1), 136-142.

Mitra, M. (2019). Keeping Up With Hanuman: Reimagining the Myth of Hanuman through Animation. Denison Journal of Religion, 18(1), 7.

Mudlofir, A. (2013). Pendidikan Karakter Melalui Penanaman Etika Berkomunikasi dalam Al-Qur'an. Jurnal Islamica, 5(2).

Qayyum, A., \& Mahmood, Z. (2015). Role of Social Media in the Light of Islamic Teaching. Al Qalam,(December), 27-36.

Ramji, R. (2016). From navy seals to the siege: Getting to know the Muslim terrorist, Hollywood style. Journal of Religion \& Film, 9(2), 6.

Rohman, A. (2016). Pembiasaan sebagai Basis Penanaman Nilai-nilai Akhlak Remaja. Nadwa, 6(1), 155-178.

Saleem, M., \& Ramasubramanian, S. (2019). Muslim Americans' responses to social identity threats: Effects of media representations and experiences of discrimination. Media Psychology, 22(3), 373-393. 
Sayfo, O. (2018). Mediating a Disney-style Islam: The Emergence of Egyptian Islamic Animated Cartoons. Animation, 13(2), 102-115.

Syafi'i, A. G. (2017). Warna Dalam Islam. Jurnal An-Nida', 41(1), 62-70.

Turmuzi, A. (2013). Mengingat dan MemahamiKembali tentang Teori Taksonomi Bloom.

Umar. (2014). Peran dan Fungsinya dalam Pembelajaran. Al-Afkar: Jurnal Keislaman Dan Peradaban, 131-144.

Xu, W. W., Park, J. Y., Kim, J. Y., \& Park, H. W. (2016). Networked cultural diffusion and creation on YouTube: An analysis of YouTube memes. Journal of Broadcasting \& Electronic Media, 60(1), 104-122. 